\title{
Misinterpretations in English-Kimuthambi Church Sermons
}

\author{
Ireri Humphrey Kirimi \\ Ikuu Girls High School, Kenya \\ E-mail: irerih@yahoo.com \\ Muriungi Kinyua Peter \\ Chuka University College, Kenya \\ E-mail: muriungip@yahoo.com \\ Waita Njogu \\ Chuka University College, Kenya \\ E-mail: znwaita@yahoo.com
}

Received: October 23, 2012

Accepted: December 2, 2012

Published: December 5, 2012

doi:10.5430/elr.v1n2p88

URL: http://dx.doi.org/10.5430/elr.v1n2p88

\begin{abstract}
Interpretation is a complex task for it involves the rendering of an oral message from one language to another simultaneously. This paper looks at misinterpretations in English-Kimuthambi church sermons in Muthambi Division, Maara District-Kenya. Kimuthambi is a Bantu language spoken in Kenya. The paper lists misinterpretations in English-Kimuthambi church sermons, identifies words and phrasal categories frequently misinterpreted in English-Kimuthambi church sermons and then provides some explanations to the misinterpretations. The paper establishes that there are misinterpretations in English-Kimuthambi church sermons. It presents the findings which show that that verbs and verb phrases are the most frequently misinterpreted categories followed by the nouns and noun phrases. The findings in this paper contribute to the scholarly literature in interpretation and translation which traverses different levels of language study like translation, discourse analysis, semantics and pragmatics.
\end{abstract}

Keywords: Misinterpretations, Kimuthambi, Back interpretation (BI), Functional equivalence (FE)

\section{Introduction}

Interpretation of oral messages in many parts of the world has become common especially if people gathering do not understand the language in use. To communicate therefore, there has to be somebody assuming the role of a communicator not only in social-political and economic spheres, but also in religious meetings. To accurately interpret a message delivered in a particular language, and then effectively communicate the same in another language, is a complex but vital task.

Available research shows that interpretation is necessary if people speaking different languages have to communicate effectively. Kruger (1994) posits the need to have an interpreter in order to prevent linguistic exclusions. He particularly calls for the removal of obstacles to communication. This he says is enhanced by providing a clear, direct and effective voice to those who would otherwise not understand what is being said in a different language. Additionally, to enhance communication, the interpreter has to remove obstacles by providing those who depend on the interpretation with a full and complete message. As a process therefore, the result of transferring a text from a source language (SL) into a target language (TL) is necessary.

Interpretation in the Kenyan churches has increased with the increase of Pentecostal churches. From the colonial period to the late eighties, the main-stream churches had dominated the religious scene in Kenya. These churches vouched for the use of the local dialects as much as possible. Even currently these churches insist that mother tongues dominate the church programme thus utilizing only preachers who can speak the local language. On the contrary, most Pentecostal churches allow even preachers who cannot speak the local language with the intention of 
involving an interpreter. Interpretation has been so much emphasized that some preachers who well understand the local language of the congregants may choose to use English language with an interpreter.

In the course of these interpretations, many misinterpretations occur thus affecting the message delivered. This is especially because interpretation is more critical than translation of written text for it demands that the interpreter keeps interpreting the speaker's message at every point. Much has been done in the area of translation of written text but little has been done to find out misinterpretations that occur in Interpretation. This paper investigates misinterpretations that arise in the process of interpreting sermons delivered in English into Kimuthambi dialect. It is guided by the following objectives:

i. To identify misinterpretations in English-Kimuthambi church sermons.

ii. To identify words and phrasal categories frequently misinterpreted in English- Kimuthambi church sermons.

iii. To provide linguistic explanations to the misinterpretations.

\section{Literature Review}

Various studies on mistranslations have been conducted. Ali (1981), Omboga (1986) and Gimode (2006) examined mistranslations regarding translation from English to Kiswahili. They discovered that translators involved in this process make many errors mainly because of lack of training, low level of education and high speed. Ali's work was based on the errors that occurred in the then V.O.K Kiswahili news broadcasting and she demonstrated that the errors were caused by incompetence among translators, the short length of time within which the news was written and other non-linguistic factors.

Gimode (2006) cited that further studies could be done involving English and another language other than Kiswahili since she expected that a different receptor language and setting would bring about different findings. This study analyzed misinterpretations in English-Kimuthambi sermons within a rural context . The difference between this study and Gimode's is great because of differences in receptor language structure, audience exposure, literacy level and general sociolinguistic context. Unlike in earlier studies, where the rendering of sense from one language to another orally is referred to as translation; this study used the term interpretation which it proposed to be more appropriate than the term translation.

Wangia (2003) examined aspects of mistranslations in the 1957 Luloogoli Bible. She looked at different types of translation problems using various linguistic indicators. She noted that the Luloogoli Bible is an example of a translation with great historical, cultural and linguistic contrast from the original text perspective. Therefore, she sites language problems that are the centre of translation problems such as structure, ambiguity, obscurity and figurative expressions. These issues would easily lead to mistranslations and therefore need to be resolved. This study was based on two languages which are structure-wise very different. Wangia's findings were therefore very useful since this research also involved two very different languages: that is English and Kimuthambi. Morpho-syntactically English is mainly regarded as an isolating language, while Kimuthambi an agglutinating language.

Kariuki (2004) studied comprehension problems that Gikuyu speakers faced in trying to understand the 2004 draft constitution of Kenya. He outlined the discrepancies men and women exhibited in comprehension and interpretation of the constitution. He also noted the need to preserve important documents in a first language. He emphasized the need for translation strategies that would bear the equivalence of an important document.

Wanjohi (2004) highlights a systematic procedure that could be followed in creation of Gikuyu neologism. Considering the fact that some professionals are compelled by the nature of their work to engage in a lot of translation, she underscores the importance of the media in the propagation of new terminologies. She also identifies some scientific and technical terms that the Gikuyu F.M radio presenters encounter in their effort to provide equivalent terms. She notes that some strategies would not be effective tools of propagating indigenous vocabulary. These findings are vital to this research since misinterpretations may occur because some English biblical terms do not have obvious Kimuthambi language equivalents.

\section{Theoretical Framework}

The research was guided by the interpretive theory of translation by Marianne (2003). The theory posits that the process of translation involves, understanding the message from the source text, interpreting it and then transmitting what is understood to the audience. That is sense for sense as opposed to word for word. The theory identifies the mental and cognitive processes involved in both oral and written translation: understanding the text, deverbalizing its language and re-expressing sense. 
This theory is very vital for this study because it advocates that the interpreter interprets the message from the preacher and communicates the concept to the audience rather than striving to translate word for word. In this view therefore the study established that many misinterpretations that occur during English to Kimuthambi church sermons interpretations are due to word for word translation. The research confirmed that interpreting the preacher's utterance then communicating the interpreter's understanding of the message reduces misinterpretations.

\section{Population}

The population for this study was all the English-Kimuthambi church sermons preached in Pentecostal churches in Muthambi division, Maara district, Kenya. This research borrowed from Gimode (2006) who used five sermons in her research. The researcher therefore utilized five sermons from five different churches for diversity. There were fifteen Pentecostal churches in Muthambi Division which had similar characteristics. The researcher used simple random sampling procedure to identify five churches from which the five sermons were recorded.

\section{Methods of data collection}

A voice recorder was used to record one sermon from each of the sampled churches. The researcher informed the church authorities before doing this so as not to impinge on the interpreters' rights (Milroy, 1987). The researcher also used a checklist on which the misinterpretations were transcribed.

\section{Methods of Data Analysis}

The study employed descriptive statistics to analyze the data obtained. Gray (1981) asserts that descriptive survey data is commonly presented through use of frequency counts, graphs, frequency tables and pie-charts.

The researcher listened to the sermons, identified and wrote down misinterpretations on a checklist. Next the researcher identified words and phrasal categories frequently misinterpreted from those misinterpretations and provided their back interpretations and functional equivalents. The researcher also categorized the misinterpretations into simple misinterpretations, under and over interpretations. Findings are presented using frequency tables and charts showing the percentage scores. To ensure that categorization was systematic, the word and phrasal categories were differentiated as: Nouns and noun phrases, verbs and verb phrases, adjectives and adjectival phrases, adverbs adverbial phrases, prepositions and prepositional phrases, pronouns, determiners, conjunctions and interjections. Finally the researcher provided a discussion on the linguistic causes of misinterpretations.

\section{Misinterpretations in English Kimuthambi Church Sermons}

The misinterpretations presented in this section were elicited from five sermons recorded from five different churches. The data has been analyzed in the view of the interpretive theory of translation. Though the study is mainly qualitative due to the detailed descriptions of the trends exhibited by the data, quantitative analysis is also employed in the presentation through the use of charts to represent the frequency of misinterpretations among word and phrasal categories. In data presentation the abbreviations E, K, B.T and F.E have been used. E represents the English version, K, Kimuthambi version, B.I, back interpretation and F.E to show the functional equivalence; that is the intended meaning for the misinterpreted form. Back Interpretation refers to interpreting a word or a phrase back into the English language after being interpreted into Kimuthambi in order to test its accuracy.

The back interpretation will enable those who do not understand Kimuthambi dialect to easily access this work. All the italicized items in Table 1 constitute misinterpretations that occurred during the church sermons interpretation.

Insert Table 1 here

\subsection{Frequency of Misinterpretations among Word and Phrasal Categories}

The word and phrasal class categories pose different levels of difficulty as is illustrated in these findings. The categories considered in this section are: verbs and verb phrases nouns and noun phrases, adjectives and adjectival phrases, prepositions and prepositional phrases, adverbs and adverbial phrases, pronouns, interjections, conjunctions and determiners. Since it is grammatically difficult to distinguish between words and phrases, the misinterpretations of word or phrasal nature of a particular category were grouped together. For instance the term John is a single word but can function as a noun phrase. It can be replaced by the pronoun 'he' just like the phrase 'the boy'.

Thirty seven clauses were isolated for having misinterpretations, verbs and verb phrases was identified as the category most frequently misinterpreted among the word categories. Out of the forty misinterpretations of various categories, 15 were either verb or verb phrases accounting for $37 \%$ of all the misinterpreted forms. Nouns and noun phrases came second at $27 \%$, adjective and adjectival phrases were third at $15 \%$, adverbs and adverbial phrases came fourth at $13 \%$, prepositions fifth with $5 \%$ and pronouns came sixth at $3 \%$. Determiners, interjections and 
conjunctions did not record any misinterpretations. The combined number of words and phrasal categories misinterpretations were forty items distributed as illustrated:

$\begin{array}{lll}\text { Verbs and Verb phrases } & 15 / 40=37 \% \\ \text { Nouns and Noun phrases } & 11 / 40=27 \% \\ \text { Adjectives and Adjectival phrases } & 6 / 40=15 \% \\ \text { Adverbs and Adverbial phrases } & 5 / 40=13 \% \\ \text { Preposition and Prepositional Phrases } & 2 / 40=5 \% \\ \text { Pronouns } & 1 / 40=3 \% \\ \text { Conjunctions } & 0 / 40=0 \% \\ \text { Interjections } & 0 / 40=0 \% \\ \text { Determiners } & 0 / 40=0 \%\end{array}$

\subsection{Linguistic Explanations to Misinterpretations}

Most misinterpretations (67\%), simply didn't capture the message intended by the preacher and are thus categorized as simple misinterpretations. $23 \%$ presented the message in a lighter manner compared to the preachers' message and are categorized as under interpretations while $10 \%$ presented the message in a weightier manner compared to the preachers' message and are therefore categorized as over interpretations. The frequencies according to nature of misinterpretations are as follows:

$\begin{array}{lll}\text { Simple misinterpretations: } & 27 / 40 & =67 \% \\ \text { Under Interpretations: } & 9 / 40 & =23 \% \\ \text { Over Interpretations: } & 4 / 40 & =10 \%\end{array}$

The most frequently misinterpreted word and phrasal category according to the analysis on figure 4 , is the verb (37\%). This can be generally explained by the fact that most preachers utilize action words to make the message come alive. Nouns too record a high frequency of misinterpreted forms $(27 \%)$ and this can be explained by the fact that they are content words and sometimes a Kimuthambi word that is equivalent to a certain English word could not be easily found. Adjectives and adjectival phrases came third at (15\%), followed closely by adverbs and adverbial phrases (13\%), prepositions and prepositional phrases $(5 \%)$ and then the pronouns $(3 \%)$. No misinterpretation was recorded that was of the nature of determiners, conjunctions and interjections. Each category that had misinterpretations is discussed in details below.

\subsection{Verbs and Verb Phrases}

Verbs generally refer to words that denote actions or state of being. For example sell, run and appear. The morphology of English and Kimuthambi differ greatly. For instance, although the English verb may be marked for aspects such as person and number, it still varies greatly from the Kimuthambi verb phrase. Kimuthambi is a dialect of an agglutinating language whose verb morphology contains a subject marker, tense, number, aspect, voice and person all fused into a single word. For instance the English sentence 'He hit me' has three words; the subject 'he', the verb 'hit' and the object 'me'. The Kimuthambi equivalent of the sentence above is 'niandingire'.

Most misinterpretations in the sermons sampled were noticed in verbs. The main reason for this could be that most sermons are action oriented and therefore verbs are the words that are used more than the others. The preachers were bound to make requests, give orders, or plead among other actions.

Many misinterpretations occurred when verbal elements interpreted individually, word for word. To avoid these errors, the interpreters should have interpreted the concept communicated by the verb phrase thus avoid word for word interpretation.

Some misinterpretations could have been as a result of the interpreters' linguistic incompetence in the English language. Sometimes the interpreter quickly used any word that he/she thought could stand in for the one that he or she found difficult to interpret. Consider for instance the examples below.

Misinterpretation number 3

Preacher: When you understand the position you have

Interpreter: Riria ukamenya kanya karia winako 
B.I When you know the position you have

F.E Riria ukelewa kanya karia winako

Misinterpretation number 18

Preacher: $\quad$ We must understand God

Interpreter Ni lasima twone Ngai

B.I We must see God

F.E Ni lasima twelewe Ngai

In misinterpretations number 3 and 18 above, the interpreter uses different words for the verb 'understand'. The words used do not convey the preacher's message.

Most verbal misinterpretations involved full phrases and sometimes the entire clauses. Some single word verbs in English required more than one Kimuthambi word while some verb phrases required just a single Kimuthambi word. This is illustrated using the examples below:

Misinterpretation number 13

Preacher: We are trying to squeeze ourselves here

Interpreter: Nika tukugeria gutindikana guku

B.I: $\quad$ We are trying to push one another here

F.E: $\quad$ Nika tukugeria gwitindikiria guku

In the misinterpretation number 13 above, the verb phrase 'squeeze ourselves' required a single Kimuthambi verb 'gwitindikiria'. The interpreter used the verb 'gutindikana' which in the back interpretation means 'push one another'. This interpretation missed the concept of the original message. The preacher was explaining to the congregants that the room they were using for worship was small and since they could not fit, they were trying to squeeze themselves so that they can fit. His message was meant to challenge them to contribute generously that day, since it was a fundraising day, so that they can build a bigger church hall.

The interpretation 'push one another' had a negative connotation for it suggested that the members would deliberately push each other as if in contest of something and maliciously. To avoid misinterpretations is such cases; the interpreter ought to have understood the message himself before relaying the same to the audience. He/she should do this taking the context of situation into perspective so that he is not a passive reflector but a synthesizer and a communicator by himself.

Misinterpretation number 15

Preacher: People start going in rounds

Interpreter: Antu bambagiria kuthiira ithiururiri

B.I: $\quad$ People start walking inside circles

F.E: $\quad$ Antu bambagiria kuthiururukania

In the misinterpretation number 17, the interpreter went for word-for-word interpretation which turned out absurd. The preacher was explaining how some people are not forthright when asked to account for their actions. 'They start going in rounds' that is they engage circumlocutions. The interpretation went literal and when back interpreted it suggested that they walk inside circles. This misinterpretation could have been avoided if the interpreter understood the concept that the preacher intended to communicate rather than trying to interpret separate linguistic elements.

\section{Misinterpretation number 16}

Preacher: You will not strive to get it

Interpreter: Utirutha no atia kugwata

B.I: $\quad$ You will not do anything to get it

F.E: $\quad$ Uting'anga'na kumigwata

In misinterpretation number 16, the interpreter missed the concept of 'not striving' and interpreted it as 'not doing anything'. The interpretation seemed to encourage laziness since the preacher's message could have been misconstrued to be encouraging the congregants not to work hard for they would succeed anyway provided they 
believe in God. The preacher's message on the contrary, indicated that those who trust in God will find fruit for their labor.

\section{Misinterpretation number 24}

Preacher: He sent the crowd away

Interpreter: Akinga gikundi

B.I: $\quad$ He chased the crowd

F.E: $\quad$ Akira gikundi kithi

The Oxford Dictionary of phrasal verbs defines a phrasal verb as the combination of a verb and an adverb, a verb and a preposition, or a verb, an adverb, and a preposition which functions as a unit of meaning. The unit can only be interpreted jointly. Since Kimuthambi does not have phrasal verbs, misinterpretations occurred when interpreters attempted to interpret the verbs as separate entities from their counterparts. Some phrasal verbs may have multiple meanings and others have collocates. That is they are used in particular contexts. For instance the concept of 'sending away' in English does not have a negative connotation in the context in which it was used. It meant that Jesus asked people to leave. The Kimuthambi interpretation 'Akinga gikundi' is an over interpretation and it connotes forcing people out of a place.

\section{Misinterpretation number 5}

Preacher: $\quad$ Wave at me please

Interpreter: Mbukiririani njara

B.I: $\quad$ Lift your hands at me please

F.E: $\quad$ Nketheriani rierani

The interpretation 'lift your hands at me' in the misinterpretation above is an under-interpretation. The interpreter failed to quickly capture the message. 'Lifting hands' being very different from 'waving', only those who understand English waved. Those who didn't understand English language, waved after they saw others doing so. It seemed difficult for the interpreter to get a Kimuthambi word for 'wave', but the concept could be appropriately captured by the phrase 'nketheriani rierani'.

\section{Misinterpretation number 26}

Preacher: You are graduating

Interpreter: Gogukura

B.I: $\quad$ You are growing up

In some instances the interpreters were not well versed with the Kimuthambi equivalents of the English verb eventually picking a word from their experiential vocabulary closely related to the English word. For example in misinterpretation number 26, the concept of 'You are graduating' was interpreted as 'Gogukura' which in the back interpretation is 'You are growing up'. This remotely captures the concept of 'graduating'. The concept of graduation, though foreign to the Kimuthambi speakers, is familiar to almost all the congregants. In that case, therefore, it would have been appropriate for the interpreter to code mix and co-opt the term in his interpretation. This is because the chief end of interpretation and translation is communication. The interpreter could have for instance said 'goku-graduate' and all the congregants would have understand what he or she meant.

Misinterpretations in tenses also occurred. For instance in misinterpretation number 7 the meaning was completely altered.

\section{Misinterpretation number 7}

Preacher: We have been here for the last seven years

Interpreter: Twii aa miaka mugwanja

B.I: $\quad$ We are here for seven years

F.E: $\quad$ Twithiritwe twi aa miaka mugwanja

The interpretation insinuated that they would be in that church hall for another seven years, while the preacher meant that they had already been in that church hall for seven years and therefore they needed to move to another place. The present tense was interpreted to sound futuristic. 
Misinterpretation number 1 occurred because the interpreter ignored the tense in the English version:

Misinterpretation number 1

Preacher: This is one of the last Sundays we are here

Interpreter: Ino nio Sunday ya mwisho twi aa

B.I: $\quad$ This is the last Sunday we are here

F.E: $\quad$ Ino nimwe ya Sunday jia mwisho twi aa

Following the interpretation in the misinterpretation number 1 above, the interpreter communicated that that day was the last for the congregation to meet in that church hall while the preacher had said that, that Sunday was one of the last. Therefore according to the preacher, they would meet in the same church hall a few more times.

Most languages of the world are divided into three types: Inflectional for example Latin, Agglutinating for example Kimuthambi and Kiswahili, isolating for example Chinese and polysynthetic for example Chukchi and Eskimo.

In agglutinating languages words consist of more than one morpheme while in inflectional language forms are always made up of clearly identifiable parts. In most cases the entire verb phrase expresses a single idea within various dimensions such as tense, mood, voice aspect, among others. When an interpreter begins to give each verbal element an independent interpretation, misinterpretations are bound to occur. English being majorly an isolating language, it typically lists most verbal elements separately while in Kimuthambi all the verbal elements are fused into one word for phonetic realization. The interpreter failed to harmonize the syntactic differences between the two languages.

\subsection{Nouns and Noun Phrases}

Nouns refer to words that name people, places and all things in general. Some of the things may be concrete like: bag, John and pulpit while others may be abstract like angel, joy and peace. The naming may be specific or general and it may also incorporate a collection of many things together; for example a troupe of soldiers or a congregation of worshipers.

In this study a total of eleven nouns and noun phrases were misinterpreted out of the forty word and phrasal category misinterpretations This accounts for $27 \%$ of all the misinterpretations. The following is a list of some of the misinterpreted nouns, their back interpretations and functional equivalences.

Insert Table 2 here

The word 'perfector' in the misinterpretation number $2:$ 'Jesus is the perfector of our faith was misinterpreted as 'muthiria' which when back-interpreted is 'Finisher'. The interpreter, it appears, didn't have a ready 'word for word' equivalent in the Kimuthambi dialect thus the occurrence of this simple misinterpretation. Using the interpretive theory of translation, the message would have been communicated more appropriately if the noun was interpreted as 'mukinyaniriria'.

The noun 'vision' in the misinterpretation number 4: 'The power of vision' was misinterpreted as 'kwona' when back interpreted it is 'seeing'. 'Seeing' is a gerund and did not capture the message communicated through the noun 'vision'. It was an under-interpretation because, though it tried to indicate the meaning intended, it fell short of the exact by far. The Kimuthambi word that would have rightly captured the concept of a vision is 'kioneki'

The noun 'chaos' in the misinterpretation number 12: 'Then she heard chaos' was misinterpreted as 'migambo' which if back-interpreted it is 'sounds'. This is under-interpretation because the noun sounds did not capture the concept communicated by the word 'chaos'. The word 'chaos' is of a greater magnitude than sounds. The noun 'warning' in misinterpretation number 29: 'fire is a warning' was interpreted as 'kionereria'. It is a simple misinterpretation completely off the intended meaning. The back-interpretation is 'example' yet the fuctional equivence for 'warning' in Kimuthambi is 'gikania'

In misinterpretation number 30: 'There is a tree called the Meru oak' the name of the tree was interpreted literary as 'Muti wa Mumiru'. Meru Oak is a name of a tree which in Kimuthambi is referred to as 'Muuru'. The back-interpretation for the misinterpreted noun is 'the tree of a Meru' which sounds absurd.

The other noun that was misinterpreted was the noun 'storms' in the misinterpretation 'storms will come to you'. It was interpreted as 'rukungi' which in the back-interpretation is 'wind'. This is an under-interpretation because the term 'winds' does not capture the meaning in the word 'storms'. The word 'storm' captures not just winds but much more confusion and havoc. The word that captures the concept accurately is 'ibubania'. 


\subsection{Adjectives and Adjectival Phrases}

According to the Oxford Advanced Learners Dictionary, adjectives generally refer to words that describe people or things. They are basically used to modify nouns, for example: red ball, big house and clever girl. Adjectives accounted for $15 \%$ of all the word category misinterpretations that occurred. Some of the misinterpretations of adjectival nature are explained.

Misinterpretation number 1

Preacher: This is one of the last Sundays we are here

Interpreter: Ino nio Sunday ya mwisho twii aa

B.I: $\quad$ This is the last Sunday we are here

F.E: $\quad$ Ino nimwe ya Sunday jia mwisho iria twii aa

Misinterpretation number 8

Preacher: They were tested by the physical eyes

Interpreter: Bagerirwe na metho makwona

B.I : $\quad$ They were tested by seeing eyes

F.E : $\quad$ Bagerirwe na metho mamwiri

The phrase 'one of the last' in misinterpretation number 1 pre-modifies the noun Sunday. The interpreter ignored the words 'one of' and interpreted only 'the last' before the noun Sunday. This completely altered the meaning of the source text.

In misinterpretation number 8 , the preacher mentioned 'physical eyes' in an attempt to show that there are other 'eyes' that do not function like the usual eyes of human beings. 'Physical' in this context should have been associated with the body.

Misinterpretation number 14

Preacher: Financial breakthrough

Interpreter: Gucindana na mbesa

B.I : $\quad$ Competing with money

F.E : $\quad$ Kugia na mbesa

The adjectival phrase 'financial breakthrough in misinterpretation number 14 is a common phrase in religious forums which insinuates that one has been able to get enough money to live on. Using the interpretive approach, the interpreter should have understood this message and then communicate it in his or her own words.

A property can be ascribed by placing adjectives after a form of the verb 'to be' to form a sentence. That is by applying predicative adjectives. For instance, instead of having 'the big man' we have 'the man is big'. Let's consider the examples below:

Misinterpretation number 28

Preacher: $\quad$ The seed may appear attractive

Interpreter: Mpindi noyoneke ingemie

B.I : $\quad$ The seed may appear decorated

F.E : $\quad$ Mpindi noyoneke imbega

In misinterpretation number 28 , the preacher was trying to emphasize inner beauty over and above external beauty. He illustrated this using a seed and claimed that what mattered for a seed to grow was the inside and not the outward beauty. The interpreter misinterpreted the adjective 'attractive' as 'decorated'. This interpretation didn't capture the concept as intended.

\subsection{Adverbs and Adverbial Phrases}

Adverbs are words that modify verbs, adjectives or other adverbs indicating how, when or why something happened or the degree to which a property characterized an individual or an event. The adverb performs a wide range of functions within a sentence in English grammar. 
Five adverbs and adverbial phrases were misinterpreted in the sermons recorded for the purposes of this study. This accounted for $13 \%$ of all the word and phrasal categories misinterpretations. The following is an example.

\section{Misinterpretation number 11}

Preacher: Use your eyes positively

Interpreter: Tumira metho maku kwona muno

B.I: $\quad$ Use your eyes to see alot

F.E: $\quad$ Tumira metho maku na njira imbega

In misinterpretation number 11 above, the adverb of manner 'positively' was interpreted literary therefore the intended meaning was lost. The preacher was challenging the congregants not to look at things that are not helpful thus they use their eyes well. The adverb positively is a general term that is meant to capture anything done well. The interpreter therefore should not have struggled to render the literal meaning.

\subsection{Prepositions and Prepositional Phrases}

The Oxford Advanced learners Dictionary defines a preposition as a word or a group of words, such as in, from, to, out of and on behalf of, used before a noun or a pronoun to show place, position, time or method. Misinterpretations of the prepositional nature were (5\%). Most misinterpretations occurred within the same class. They involved just an interchange of a preposition and the whole concept was lost. Consider the two instances illustrated below.

Misinterpretation number 20

Preacher: $\quad$ If you sin, run to God

Interpreter: Weyia tamuka Ngai.

B.I: $\quad$ When you sin run from God.

F.E: $\quad$ Ukeja kwiyia tamuka ki Ngai.

Misinterpretation number 23

Preacher: The philistines are too many for me

Interpreter: Afilisti nibaingi kini

B.I: $\quad$ The philistines are more than me

In misinterpretation number 23 above, the interpreter completely missed the message that the preacher intended to deliver. The preacher was advising the congregants on what to do in case one sins, and he said 'run to God' not 'from God'. The interpreter interchanged the prepositions to and from and the message was completely distorted for it implied that if one sins, they should depart from Gods sight rather that move to his as was communicated in the source text. Either the interpreter was not conscious of the interpretation she was giving, or was unaware of these prepositions or she was giving her own interpretation of the concept in question.

In misinterpretation number 23, the interpretation was affected by mother tongue interference. The interpreter, it appears, did not have the in depth competence of the English expressions and constructions and so was quick to interpret literary rather than ponder the expected communication. The phrase 'too many for me' has the concept of not only number but also ability. The preacher meant that the philistines were too many that logically they would overpower and subdue him. The interpretation captured just the number and so it was an under-interpretation.

\subsection{Pronouns}

Pronouns refer to words that are used instead of nouns or noun phrases, for example he, it, hers, mine and them. There are many types of pronouns: personal, demonstrative, interrogative, possessive and relative.

Out of all the word categories misinterpretations analyzed in this study, 3\% were pronouns. The second person pronoun 'you' in English remains the same both in the singular and plural. This is not the case in Kimuthambi. The interpreter sometimes addressed one person when the preacher had addressed all and vice versa. The illustration below substantiates this.

\section{Misinterpretation number 34}

Preacher: A storm will come to you

Interpreter: Rukungi rugakwijira 
B.I: $\quad$ Wind will come to you

F.E: $\quad$ Ibubania igakwijirira

The interpreter interpreted the pronoun 'you' in the misinterpretation number 34 above as a plural. She assumed that, since the preacher was obviously preaching to many people, then the pronoun must be in the plural. The preacher had just given his personal experience showing how he had passed through a difficult time. Though he was addressing a big congregation, he was stylistically addressing an individual in order to evoke greater effect on the listeners. It is obvious that the pronoun 'you' in the utterance 'storms will come to you' is singular.

\subsection{Conjunctions, Interjections and Determiners}

Conjunctions refer to words that join words, phrases or sentences. For example; and, but, and or. Interjections refer to short sounds, words or phrases spoken suddenly to express an emotion. For example; oh! , look out! and ow!. Determiners are words that are used before nouns to indicate whether one is referring to something specific or something of a particular type. For example; the a, and some. These word categories did not indicate any misinterpretations.

\section{Summary}

The following is the summary of what the study found out:

i. There are misinterpretations in English Kimuthambi church sermons.

ii. Some word and phrasal categories are more prone to misinterpretations than others.

iii. The verb and the verb phrase are the most frequently misinterpreted categories.

iv. Determiners, conjunctions and interjections did not record any misinterpretations

v. Majority of the misinterpretations were simple misinterpretations followed by misinterpretations due to under interpretation and finally the misinterpretations due to over interpretation.

\section{Conclusion}

From the above findings, it can be concluded that there are misinterpretations in English Kimuthambi church sermons that distort the message intended by the preacher. These misinterpretations are majorly based on action words; that is, they are verbal. Many others are names of people, things, places or concepts; that is, nouns and noun phrases while a good number are adjectival and adverbial. Very few are prepositional and pronoun based. None are determiners, conjunctions and interjections. It can be further noted that most misinterpretations were simple. Quite a number were due to under interpretation and very few due to over interpretation.

\section{Recommendations}

It is evident from the findings in this paper that there are misinterpretations in English Kimuthambi church sermons and that they occur more frequently in some word and phrasal categories and they can be linguistically explained. The following recommendations are done based on the findings of the research:

i.Preachers and Interpreters of the English-Kimuthambi church sermons should be made aware that there are misinterpretations in English-Kimuthambi church sermons. This awareness should be geared towards making the interpreter more alert as he or she interprets and the preacher more articulate and careful in his or her presentation so that they can avoid many misinterpretations.

ii. Interpreters should take extra caution when interpreting verbs and verb phrases because the study shows they pose the greatest challenge to English-Kimuthambi interpretation. To reduce misinterpretations in this category, churches should utilize linguistically competent interpreters in both languages; that is those competent in both the source language and the receptor language since the verbs and the verb phrases are not easily predictable even when the sermon outline is available.

iii. The interpreter should preview the sermon to be preached and note the nouns that the preacher intends to use. $\mathrm{He}$ or she should confirm the names of various biblical characters from the text of the sermon and the names of places, things and concepts on the sermon or sermon outline. This would greatly reduce misinterpretations of the category of the noun and the noun phrase.

iv. Interpretation should be majorly done concept by concept rather than word for word as already suggested by the interpretive theory. 
v.Interpreters need to study and understand translation and interpretation theories. An understanding of interpretation problems will enable interpreters to arrive at better solutions when faced with challenging situation in the process of interpretation.

vi. Church interpreters should attend formal training or attend workshops and seminars on translation and interpretation so that they are adequately equipped with interpretation strategies.

vii. Interpreters should be exposed to interpretive works by other seasoned interpreters by way of audio, video or other means so that they can gain and enhance appropriate prosodic skills among others.

\section{Suggestions for Further Studies}

The findings in this study have elicited pertinent concerns that warrant further research. The following are recommended for further research.

i. The verb phrase was discovered to be the category most prone to misinterpretation in English-Kimuthambi church sermon Interpretation. A further study is recommended to find out the challenges of interpreting the English verb phrase into Kimuthambi.

ii. Misinterpretations occur in most churches due to incorrect interpretation of linguistic units. Other than Kimuthambi, interpretation from English language into many other Kenyan languages and dialects is taking place in Kenyan churches. Further studies are therefore recommended between English and such languages.

\section{References}

Akbari, M. (2009). Risk Management in Translation. [Online] Available: http://www.TranslationDirectory.com] (November 3, 2009).

Ali, W. (1981). The Problems of translating from English to Kiswahili. Unpublished M.A thesis, Kenyatta University, Nairobi, Kenya.

Backland, U. (1984). Realize and Recognize. Stockholm: Wiksel International.

Ballmer, T., \& Brenner, W. (1981). Speech Act Classification. New York: Springer Verlag. http://dx.doi.org/10.1007/978-3-642-67758-8

Bills, D. (2008). How to Preach with an Interpreter. New Yolk: Penn State Press.

Brown, G., \& Yule, G. (1988) Discourse Analysis. Cambrige: Cambridge University Press.

Burns, R. (2000). Introduction to Research Methods. London: SAGE Publication Limited.

Cartford, J. (1965). A Linguistic Theory of Translation. London: Oxford University Press.

Crystal, D. (1987). Encyclopaedia of Language. Cambrige: Cambridge University Press.

Fasold, R. (1984). The Sociolinguistics of Society. New York: Basil Blackwell.

Dunning, S. (1997). A Structural Analysis of the Theory of Stages and the Tongues of Men. New Yolk: Penn State Press.

Fasold, R. (1984). The Sociolinguistics of Society. New York: Basil Blackwell.

Gaiba, F. (1998). The origins of Simultaneous Interpretation: The Nuremberg Trial. London: University of Ottawa Press.

Gimode, J (2006). Mistranslations in English-Kiswahili Church Sermon Translations: A Case Study of one Pentecostal Church in Kasarani Division-Nairobi. Unpublished M.A Thesis, Kenyatta University: Nairobi, Kenya.

Gumperz, J. (1986). Directions in Sociolinguistics, Oxford: Basil Blackwell.

Gutt, E. (1991). Translation and Relevance Cognition Context. Oxford: Basil Blackwell.

Hargie, O. (1986). Handbook of Communication Skills. London: Croom Helm.

Hartill, J. (1947). Principles of Biblical Hermerneuticss. Michigan: Zondervan Publishing house.

Hatim, B., \& Ian M. (1990). The Translator as Communicator. London: Rutledge.

Hoey, M. (1991). Patterns of Lexis in Text. Oxford: Oxford University Press.

Hudson, R. (1995). Word Meaning. London: Routledge. 
Kariuki, P. (2004). Comprehension Problems in Understanding the 2004 draft Constitution among Kikuyu Speakers. Unpublished M.A Thesis, Kenyatta University, Nairobi, Kenya.

Levinson, S. (1983). Pragmatics. Cambridge: Cambridge University Press.

Lyons, J. (1981). Language and Linguistics. Cambridge: Cambridge University Press.

Marianne, L. (2003). The Interpretive Model. Manchester: St Jerome.

Milroy, L. (1987). Observing and Analysis of Nature Language: A critical Account of Sociolinguistic Method. Oxford: Basil Blackwell.

Mugenda, O., \& Abel M. (1999). Research Methods: Quantitative and Qualitative Approaches. Nairobi: Acts Press.

Mutahi, K. (1987). 'Translating problems in Oral Literature.' Lingistic Conference of S.A.D.C.C Universities (LASU). Harare: Unpublished.

New King James Version. (1982). London: Thomas Nelson.

Omboga, Z. (1986). Fasihi Tafsiri Katika Ukuzaji wa Fasihi ya Kiswahili. Unpublished M. A thesis, University of Nairobi, Nairobi, Kenya.

Ordudari, M. (2009). Translation Procedures: Strategies and Methods. [Online] Available: http://www.Translationdirectory.com (November 3, 2009).

Rogers, W.(1984). Communication in Action. New Yolk: C B S College.

Romaine, S. (1994). Language in Society: Introduction to Sociolinguistics. Oxford: Oxford University Press.

Saeed, J. (1997). Seantics. Oxford: Basil Blackwell.

Shi, Aiwei. (2009). Causes of Failure in Translation and Strategies. [Online] Available: http://www.TranslationDirector.com (Accessed 3rd November 2009).

Shuttleworth, M. (2008) Qualitative Research Design. [Online]. Availble: htt://www.experiment Resources.com (February 25, 2010).

Sperber, D., \& Deirdre W. (1986). Reference: Communication Cognition. Cambridge: Cambridge University Press.

Thorme, S. (1997). Mastering Advanced English Language. New York: Palgrave.

Virkler, H. (1981). Principles and Processes of Biblical Interpretation. Michigan: Bakerbook House Company.

Wangia, J. (2003). Aspects of Mistranslations in the 1957 Luloogoli Bible. Unpublished Ph.D, thesis, Kenyatta University, Nairobi, Kenya.

Wanjohi, J. (2004). Creation of Kikuyu Neologism. Unpublished M.A Thesis, Kenyatta University, Nairobi, Kenya. Yule, G. (1996). The Study of Language. Cambridge: Cambridge University Press.

Table 1. Misinterpretations

\begin{tabular}{|c|c|c|c|c|c|}
\hline No & Preacher & Interpreter & $\begin{array}{l}\text { Back } \\
\text { Interpretation }\end{array}$ & $\begin{array}{l}\text { Funtional } \\
\text { Equivalence }\end{array}$ & $\begin{array}{l}\text { Nature Of } \\
\text { Misinterpretation }\end{array}$ \\
\hline 1 & $\begin{array}{l}\text { This is one of the } \\
\text { last Sundays we } \\
\text { are here }\end{array}$ & $\begin{array}{l}\text { Ino nio Sunday } \\
\text { ya mwisho twi } \\
\text { aa }\end{array}$ & $\begin{array}{l}\text { This is the last } \\
\text { Sunday we are here }\end{array}$ & $\begin{array}{l}\text { Ino nimwe ya Sunday } \\
\text { jia mwisho iria twi aa }\end{array}$ & Simple \\
\hline 2 & $\begin{array}{l}\text { Jesus is the } \\
\text { perfector of our } \\
\text { faith }\end{array}$ & $\begin{array}{l}\text { Jiesu niwe } \\
\text { muthiria wa } \\
\text { witikio wetu }\end{array}$ & $\begin{array}{l}\text { Jesus is the finisher } \\
\text { of our faith }\end{array}$ & $\begin{array}{l}\text { Jiesu niwe } \\
\text { mukinyaniniriria wa } \\
\text { witikio wetu }\end{array}$ & Simple \\
\hline 3 & $\begin{array}{l}\text { When you } \\
\text { understand the } \\
\text { position you have }\end{array}$ & $\begin{array}{l}\text { Riria } \\
\text { ukamenya } \\
\text { kanya karia } \\
\text { winako }\end{array}$ & $\begin{array}{l}\text { When you know } \\
\text { the position you } \\
\text { have }\end{array}$ & $\begin{array}{l}\text { Riria ukelewa kanya } \\
\text { karia winako }\end{array}$ & Simple \\
\hline 4 & $\begin{array}{l}\text { The power of } \\
\text { vision }\end{array}$ & Inya ya kwona & $\begin{array}{l}\text { The strength of } \\
\text { seeing }\end{array}$ & Inya ya kioneki & Under \\
\hline 5 & $\begin{array}{l}\text { Wave at } \\
\text { me please }\end{array}$ & $\begin{array}{l}\text { Mbukiririani } \\
\text { njara }\end{array}$ & $\begin{array}{l}\text { Lift your hands at } \\
\text { me please. }\end{array}$ & Nketheriani rierani & Under \\
\hline
\end{tabular}




\begin{tabular}{|c|c|c|c|c|c|}
\hline 6 & $\begin{array}{l}\text { You realize we } \\
\text { are very squeezed } \\
\text { in this place }\end{array}$ & $\begin{array}{l}\text { Niukumenya } \\
\text { twibainye } \\
\text { muno antu aa }\end{array}$ & $\begin{array}{l}\text { You know we are } \\
\text { pressed in this } \\
\text { place }\end{array}$ & $\begin{array}{l}\text { Nibukwona } \\
\text { twibainyikanu guntu } \\
\text { guku }\end{array}$ & $\begin{array}{l}\text { Simple } \\
\text { Over }\end{array}$ \\
\hline 7 & $\begin{array}{l}\text { We have been } \\
\text { here for the last } \\
\text { seven years }\end{array}$ & $\begin{array}{l}\text { Twi aa miaka } \\
\text { mugwanja }\end{array}$ & $\begin{array}{l}\text { We are here for } \\
\text { seven years }\end{array}$ & $\begin{array}{l}\text { Twithiritwe twi aa } \\
\text { miaka mugwanja }\end{array}$ & Simple \\
\hline 8 & $\begin{array}{l}\text { They were tested } \\
\text { by the physical } \\
\text { eyes }\end{array}$ & $\begin{array}{l}\text { Bagerirwe na } \\
\text { metho } \\
\text { makwona }\end{array}$ & $\begin{array}{l}\text { They were tested } \\
\text { by seeing eyes }\end{array}$ & $\begin{array}{l}\text { Bagerirwe na metho } \\
\text { mamwiri }\end{array}$ & Simple \\
\hline 9 & $\begin{array}{l}\text { Whatever you } \\
\text { look with these } \\
\text { eyes }\end{array}$ & $\begin{array}{l}\text { Kiria ukona } \\
\text { methoni mama }\end{array}$ & $\begin{array}{l}\text { What you see in } \\
\text { these eyes }\end{array}$ & $\begin{array}{l}\text { O Kiria wonaga na } \\
\text { metho mama }\end{array}$ & Simple \\
\hline 10 & $\begin{array}{l}\text { Then you start } \\
\text { meditating }\end{array}$ & $\begin{array}{l}\text { Ukinambiria } \\
\text { gwiciria }\end{array}$ & $\begin{array}{l}\text { Then you start } \\
\text { thinking }\end{array}$ & $\begin{array}{l}\text { Ukinambiria } \\
\text { gwiciurania }\end{array}$ & Under \\
\hline No & Preacher & Interpreter & $\begin{array}{l}\text { Back } \\
\text { Interpretation }\end{array}$ & $\begin{array}{l}\text { Funtional } \\
\text { Equivalence }\end{array}$ & $\begin{array}{l}\text { Nature Of } \\
\text { Misinterpretation }\end{array}$ \\
\hline 11 & $\begin{array}{l}\text { Use your eyes } \\
\text { positively }\end{array}$ & $\begin{array}{ll}\text { Tumira } & \text { metho } \\
\text { maku } & \text { kwona } \\
\text { muno } & \end{array}$ & $\begin{array}{l}\text { Use your eyes to } \\
\text { see } a \text { lot }\end{array}$ & $\begin{array}{l}\text { Tumira metho maku } \\
\text { na njira mbega }\end{array}$ & Simple \\
\hline 12 & $\begin{array}{l}\text { Then she heard } \\
\text { chaos }\end{array}$ & $\begin{array}{l}\text { Riria egwire } \\
\text { migambo }\end{array}$ & $\begin{array}{l}\text { When she heard } \\
\text { sounds }\end{array}$ & Akinegwa gicangaca & $\begin{array}{l}\text { Simple and } \\
\text { Under }\end{array}$ \\
\hline 13 & $\begin{array}{l}\text { We are trying to } \\
\text { squeeze ourselves } \\
\text { here }\end{array}$ & $\begin{array}{l}\text { Nika tukugeria } \\
\text { gutindikana } \\
\text { guku }\end{array}$ & $\begin{array}{l}\text { We are trying to } \\
\text { push one another } \\
\text { here }\end{array}$ & $\begin{array}{l}\text { Nika tukugeria } \\
\text { gwitindikiria } \text { guku. }\end{array}$ & Under \\
\hline 14 & $\begin{array}{l}\text { Financial } \\
\text { breakthrough. }\end{array}$ & $\begin{array}{l}\text { Gucindana } \\
\text { kimbeca }\end{array}$ & $\begin{array}{l}\text { Competing with } \\
\text { money }\end{array}$ & $\begin{array}{l}\text { Kugia na mbeca jia } \\
\text { kwigana. }\end{array}$ & Simple \\
\hline 15 & $\begin{array}{l}\text { People start going } \\
\text { in rounds }\end{array}$ & $\begin{array}{l}\text { Antu } \\
\text { bambagiria } \\
\text { kuthiira } \\
\text { ithiururini }\end{array}$ & $\begin{array}{l}\text { People } \\
\text { walking } \\
\text { circles }\end{array}$ & $\begin{array}{l}\text { Antu bambagiria } \\
\text { kuthiururukania }\end{array}$ & Simple \\
\hline 16 & $\begin{array}{l}\text { You will not } \\
\text { strive to get it }\end{array}$ & $\begin{array}{l}\text { Utirutha noatia } \\
\text { kugwata }\end{array}$ & $\begin{array}{l}\text { You will not do } \\
\text { anything to get it }\end{array}$ & $\begin{array}{l}\text { Uting'ang'ana } \\
\text { kumigwata }\end{array}$ & Over \\
\hline No & Preacher & Interpreter & $\begin{array}{l}\text { Back } \\
\text { Interpretation }\end{array}$ & $\begin{array}{l}\text { Funtional } \\
\text { Equivalence }\end{array}$ & $\begin{array}{l}\text { Nature Of } \\
\text { Misinterpretation }\end{array}$ \\
\hline 17 & The favor of God & Utugi wa Ngai & The grace of God & Wendereri wa Ngai & Simple \\
\hline 18 & $\begin{array}{l}\text { We must } \\
\text { Understand God }\end{array}$ & $\begin{array}{l}\mathrm{Ni} \text { lacima } \\
\text { twone Ngai }\end{array}$ & We must see God & $\begin{array}{l}\mathrm{Ni} \text { lacima twelewe } \\
\text { Ngai }\end{array}$ & Simple \\
\hline 19 & $\begin{array}{l}\text { The Lord we are } \\
\text { dealing with. }\end{array}$ & $\begin{array}{l}\text { Ngai uria } \\
\text { tukung'ang'an } \\
\text { a nawe }\end{array}$ & $\begin{array}{l}\text { The Lord we are } \\
\text { struggling with }\end{array}$ & $\begin{array}{l}\text { Ngai } \\
\text { tukurutithania } \\
\text { nawe }\end{array}$ & Simple \\
\hline 20 & $\begin{array}{l}\text { If you sin, run to } \\
\text { God }\end{array}$ & $\begin{array}{l}\text { Weyia, tamuka } \\
\text { Ngai }\end{array}$ & $\begin{array}{l}\text { When you sin run } \\
\text { from God. }\end{array}$ & $\begin{array}{l}\text { Ukeja kwiyia tamuka } \\
\text { ki Ngai }\end{array}$ & Simple \\
\hline 21 & $\begin{array}{l}\text { It's a message full } \\
\text { of hope }\end{array}$ & $\begin{array}{l}\mathrm{Ni} \text { ntumiri } \\
\text { ijurite thayu }\end{array}$ & $\begin{array}{l}\text { It's a message full } \\
\text { of peace }\end{array}$ & $\begin{array}{l}\mathrm{Ni} \text { ntumiri ina } \\
\text { wirigiriro mwingi }\end{array}$ & Simple \\
\hline 22 & $\begin{array}{l}\text { You don't have to } \\
\text { give a lot to be } \\
\text { blessed }\end{array}$ & $\begin{array}{l}\text { Utibati kuruta } \\
\text { muno nikenda } \\
\text { urathimwa }\end{array}$ & $\begin{array}{l}\text { You should not } \\
\text { give so that you get } \\
\text { blessed }\end{array}$ & $\begin{array}{l}\text { To mwanka urute } \\
\text { muno nikenda } \\
\text { urathimwa }\end{array}$ & Simple \\
\hline 23 & $\begin{array}{l}\text { The philistines } \\
\text { are too many for } \\
\text { me }\end{array}$ & $\begin{array}{l}\text { Afilisti } \\
\text { nibaingi kini }\end{array}$ & $\begin{array}{l}\text { The philistines are } \\
\text { more than me }\end{array}$ & $\begin{array}{l}\text { Afilisti nibaingi } \\
\text { muno ntibaumba }\end{array}$ & Under \\
\hline 24 & $\begin{array}{l}\text { He sent the crowd } \\
\text { away }\end{array}$ & Akinga gikundi & $\begin{array}{l}\text { He chased the } \\
\text { crowd }\end{array}$ & Era kirindi kithi & Over \\
\hline
\end{tabular}




\begin{tabular}{|c|c|c|c|c|c|}
\hline 25 & $\begin{array}{l}\text { It was evening } \\
\text { time }\end{array}$ & Kwari Utuku & It was at night & Kwari kiogoro & Over \\
\hline 26 & $\begin{array}{ll}\text { You } & \text { are } \\
\text { graduating } & \end{array}$ & Gogukura & $\begin{array}{l}\text { You are growing } \\
\text { up. }\end{array}$ & Goku-graduate & Simple \\
\hline 27 & $\begin{array}{ll}\text { Not } & \mathrm{a} \\
\text { contemporary } & \end{array}$ & Ti Jiesu wa $n d i$ & Not a worldly Jesus & Ti Jiesu wa kiriu & Simple \\
\hline 28 & $\begin{array}{l}\text { Jesus } \\
\text { The seed may } \\
\text { appear attractive }\end{array}$ & $\begin{array}{l}\text { Mpindi no } \\
\text { yoneke } \text { imbega }\end{array}$ & $\begin{array}{l}\text { The seed may } \\
\text { appear good }\end{array}$ & $\begin{array}{l}\text { Mpindi noyoneke } \\
\text { igukujiriria }\end{array}$ & Under \\
\hline 29 & Fire is a warning & $\begin{array}{l}\text { Mwanki ni } \\
\text { kionereria }\end{array}$ & Fire is an example & Mwanki ni gikania & Simple \\
\hline 31 & $\begin{array}{l}\text { The Lord told me } \\
\text { to come and } \\
\text { comfort you }\end{array}$ & $\begin{array}{l}\text { Ngai ambira } \\
\text { ndibwikire } \\
\text { inya }\end{array}$ & $\begin{array}{l}\text { God has told me to } \\
\text { strengthen you. }\end{array}$ & $\begin{array}{l}\text { Ngai ambirire mbije } \\
\text { ndibumiririe }\end{array}$ & Simple \\
\hline 32 & $\begin{array}{l}\text { They said it is a } \\
\text { difficult thing }\end{array}$ & $\begin{array}{l}\text { Baugire ni untu } \\
\text { munene }\end{array}$ & $\begin{array}{l}\text { They said it is a } \\
\text { great thing }\end{array}$ & $\begin{array}{l}\text { Baugire ni untu } \\
\text { mumu }\end{array}$ & Simple \\
\hline 33 & $\begin{array}{l}\text { Prepare to be } \\
\text { peaceful }\end{array}$ & $\begin{array}{l}\text { Ibangabange } n i \\
\text { ntontu bwa } \\
\text { thayu }\end{array}$ & $\begin{array}{l}\text { Prepare yourself } \\
\text { because of peace }\end{array}$ & $\begin{array}{l}\text { Ibangabange kugia na } \\
\text { thayu }\end{array}$ & Simple \\
\hline 34 & $\begin{array}{l}\text { Storms will come } \\
\text { to you }\end{array}$ & $\begin{array}{l}\text { Rukungi rukeja } \\
\text { gwaku }\end{array}$ & $\begin{array}{l}\text { Winds will come to } \\
\text { your home }\end{array}$ & Ibubania ikakwijirira & Under \\
\hline 35 & You must obey & Butikarege & Don't refuse & No mwanka wathike & Under \\
\hline 36 & $\begin{array}{l}\text { When temptations } \\
\text { come }\end{array}$ & $\begin{array}{l}\text { Riria Mathina } \\
\text { meja }\end{array}$ & $\begin{array}{l}\text { When troubles } \\
\text { come }\end{array}$ & Riria magerio meja & Simple \\
\hline 37 & $\begin{array}{l}\text { Then you get } \\
\text { confused }\end{array}$ & $\begin{array}{l}\text { Ukinariganirw } \\
a\end{array}$ & Then you forget & Ukinatukanirwa & Simple \\
\hline
\end{tabular}

Table 2. Nouns and Noun phrases Misinterpretations

\begin{tabular}{llll}
\hline Preacher & Interpreter & B.I & F.E \\
\hline Perfector & Muthiria & Finisher & Mukinyaniriria \\
Vision & Kwona & Seeing & Kioneki \\
Chaos & Migambo & Sounds & Gicangaca \\
Favour & Utugi & Grace & Wendereri \\
Warning & Kionereria & Example & Gikania \\
Meru Oak & Muti wa Mumiru & Meru tree & Muuru \\
Storms & Rukungi & Wind & Ibubania \\
\hline
\end{tabular}

